\title{
技術報告
}

\section{電気化学検出高速液体クロマトグラフィーによる血清中銅 及び鉄の定量のための試料前処理法の比較検討}

\author{
永長 幸雄 ${ }^{\circledR}$, 石田 寿久*
}

(1991 年11月 21 日受理)

\begin{abstract}
電気化学検出高速液体クロマトグラフィーによる血清中の $\mathrm{Cu}(\mathrm{II})$ 及び $\mathrm{Fe}(\mathrm{III})$ の定量における除 タンパク操作及び試料導入前の試料調製を含めた前処理法について検討した. 血清試料の除夕ンパク処 理操作については 3 種類の方法を実施し，その分析結果と標示量の比較から以下のことが分かった. 従来からよく使用されているトリクロロ酶酸・塩酸処理法を用いた場合は, 標示量に最も近い定量値が 得られ, メ夕ノール・塩酸处理法を用いた場合も, 許容範囲内であった。しかし, 過塩素酸処理法を用 いた場合は, $\mathrm{Cu}(\mathrm{II})$ 泣許容範囲内であったが $\mathrm{Fe}(\mathrm{III})$ は負の誤差を生じた。 又, 正確な分析值を得る ために，プレカラム誘導体化法であらかじめ錯形成させた後，その試料溶液を注入すべきであることが 分かった。
\end{abstract}

\section{1 緒 言}

生体液の分析を行ういわゆる臨床検査は, 一般人の健 隶状態を把握するうえで有用であり，正確で信頼性が高 く簡易な方法が望まれる。多くの検查項目の中で，生体 中の $\mathrm{Cu}$ 及び Fe は必須元素であり, 物質代謝や輸送の ような生体プロセスを維持するのに重要な役割を果たし ている1)。従って $\mathrm{Cu}$ 及び Fe は血液の臨床分析におい て重要な測定項目であり，その金属濃度の変化は血液の 病気の指標に使われてきた2).

一般に，生体中の微量の $\mathrm{Cu}$ 及び Fe を定量する方法 として, $\mathrm{Cu}$ に対してはバソクプロイン法, $\mathrm{Fe}$ に対して はバソフェナントロリン法によるキレート生成に基づい た吸光光度分析 ${ }^{334)}$, 原子吸光分析 ${ }^{5)}$, アノーデイック・ ストリッピング・ボルタンメトリー6)が使用されてい る。近年，優れたカラム充てん剤が容易に入手できるよ うになり, 高速液体クロマトグラフィー（以下 HPLC 法と略記）は飛躍的に発展し, 検出法の進歩も相まって HPLC 法は分析法としての地位を確立したといえる.

著者の一人 Nagaosa は, 以前 8-ヒドロキシキノリン (以下オキシンと略記) を用いる電気化学検出 HPLC 法 による種々の生体物質中の $\mathrm{Al}, \mathrm{Cu}, \mathrm{Fe}, \mathrm{Mn}$ の定量につ いて報告した7). 本研究では酸性試料溶液中の $\mathrm{Cu}(\mathrm{II})$ 及び $\mathrm{Fe}(\mathrm{III})$ を同時定量するための基礎的実験条件を

* 福井大学工学部: 910 福井県福井市文京 3-9-1
検討し，管理血清の分析に適用した。すなわち，あらか じめ除タンパクした血清試料溶液に過剩のオキシンを添 加して $\mathrm{Cu}(\mathrm{II})$ 及び $\mathrm{Fe}(\mathrm{III})$ と錯体形成させた後, こ の両金属錯体をオクタデシルシリル（以下 ODS と略 記）カラムへ注入し，相互に分離した。グラッシーカー ボン作用極を $-0.40 \mathrm{~V}$ に設定して金属一オキシン錯体の 還元電流を測定し, $\mathrm{Cu}(\mathrm{II})$ 及び $\mathrm{Fe}(\mathrm{III})$ の定量を行っ た.これにより，生体中のアミン類，キノン類，アスコ ルビン酸といった他成分からの妨害を除去できると考え られる。

実際の分析では, 試料の前処理法により異なった分析 值が得られることがあり，最適な方法を選択する必要が ある。音机えに本研究では, 血清試料の前処理法とし て, 血清中のタンパク質の除去法とカラム導入前の試料 調製法について比較した。いわゆる除タンパク法として は，トリクロロ酢酸・塩酸处理法，メ夕ノール・塩酸処 理法及び過塩素酸処理法の 3 方法を, 試料調製法とし ては, プレカラム及びオンカラム誘導体化法の 2 方法 を調べた。応用例として管理血清中の $\mathrm{Cu}(\mathrm{II})$ 及び $\mathrm{Fe}$ （III）の同時定量を行い，その分析結果と標示量の比較 から最適な前処理法についての幾つかの知見が得られた ので報告する.

\section{2 実験}

\section{$2 \cdot 1$ 装置及び試薬}

装置は, 島津製作所製 LC-9A 型送液ポンプ, サヌキ 
工業製 SVI-6U7 型ループインジェクター $(100 \mu \mathrm{l})$, ODS カラム (東ソー製 TSKGEL-80TM, $4.6 \times 150 \mathrm{~mm}$, 粒径 $5 \mu \mathrm{m}$ ), 東ソー製 EC-8000 電気化学検出器, Bioanalytical System 製 TL-17A 型薄層セル，島津製作 所 R101 型記録計を使用した。アセトニトリルは, 関東 化学製特級試薬をそのまま使用し, 管理血清及びその他 の試薬は和光純薬工業製のものを用いた。

\section{$2 \cdot 2$ 実験操作}

2・2・1 定量操作 $\mathrm{Cu}(\mathrm{II})$ 及び $\mathrm{Fe}(\mathrm{III})$ を含む試 料水溶液を採り，これに $0.02 \mathrm{M}$ オキシンーアセトニト リル溶液 $5.0 \mathrm{ml}$, 更に $0.02 \mathrm{M}$ 酢酸緩衝液 $(\mathrm{pH} 4.7)$ を 加えて全量を $10.0 \mathrm{ml}$ とした。この溶液の $100 \mu \mathrm{l}$ を ODS カラムに注入し, $5 \mathrm{mM}$ オキシン, $0.2 \mathrm{M}$ 硝酸カ リウム及び $0.02 \mathrm{M}$ 酢酸緩衝液 $(\mathrm{pH}$ 4.7) を含む水/ア セトニトリル $(3: 2)$ 混合溶液を移動相として, 常に窒 素通気を行いながら $1.0 \mathrm{ml} / \mathrm{min}$ の流量で溶離した。溶 出液の検出は, 上述の薄層セル (グラッシーカーボン作 用極，銀/塩化銀参照電極，ステンレスブロック対極か ら成る) と電気化学検出器を用いて, 作用極の電位を $-0.40 \mathrm{~V}$ に設定し, 得られたピーク高さから Cu(II) 及び $\mathrm{Fe}(\mathrm{III})$ の定量を行った。

$2 \cdot 2 \cdot 2$ 実試料の前処理操作 血清試料（和光純薬 工業製管理血清 I 及び II）を除タンパクするために, 以下のような 3 通りの処理操作を施した.

$\mathrm{A}$ 法 (トリクロロ酢酸・塩酸処理): 血清 $1.0 \mathrm{ml}$ に $\mathrm{M}$ 塩酸 $0.50 \mathrm{ml}$ を加え, $80 \sim 95^{\circ} \mathrm{C}$ の温浴を約 3 分間行 い十分な放冷後, $20 \mathrm{~g} / \mathrm{dl}$ トリクロロ酢酸溶液 $0.50 \mathrm{ml}$ を加えよくかき混ぜてタンパク質塊を細かく砕いた後, 約 $2000 \mathrm{rpm}$ で 10 分間遠心分離し上澄み液をとった。 $\mathrm{B}$ 法 (メ夕ノール・塩酸処理): 血清 $1.0 \mathrm{ml}$ に $2 \mathrm{M}$ 塩酸 $1.0 \mathrm{ml}$ とメタノール $1.0 \mathrm{ml}$ を加えよくかき混ぜ約 15 分 間静置後, 約 $2000 \mathrm{rpm}$ で 10 分間遠心分離し上澄み液 をとった. C 法 (過塩素酸処理): 血清 $1.0 \mathrm{ml}$ に 6 $\mathrm{w} / \mathrm{v} \%$ 過塩素酸 $1.0 \mathrm{ml}$ を加えよくかき混ぜ, 約 15 分 間静置後, 約 $3000 \mathrm{rpm}$ で 約 15 分間遠心分離し上澄み 液をとった。この一回の遠心分離では, 上澄み液に浮遊 物がある場合が多いので, 更に上澄み液を採取し再度遠 心分離する必要があった。 $\mathrm{A}$ 及び $\mathrm{C}$ 法は, 上澄み液 $0.40 \mathrm{ml}$ が血清 $0.20 \mathrm{ml}$ に相当するとみなし, B 法は, 上澄み液 $0.60 \mathrm{ml}$ が血清 $0.20 \mathrm{ml}$ に相当するとみなして 血清中の $\mathrm{Cu}(\mathrm{II}), \mathrm{Fe}(\mathrm{III})$ の定量値を求めた.

次いで，このようにして得られた血清試料は，カラム に注入する前に 2 通りの方法で溶液調製した。まずオ キシンによる $\mathrm{Cu}(\mathrm{II})$ 及び $\mathrm{Fe}(\mathrm{III})$ へのプレカラム誘
導体化クロマトグラフィーでは, 除タンパク処理した血 清試料溶液 (上澄み液) $1.0 \mathrm{ml}$ に, $0.5 \mathrm{M}$ 酢酸ナトリウ ム溶液 $3.0 \mathrm{ml}$ と $0.05 \mathrm{M}$ オキシンーアセトニトリル溶液 $1.0 \mathrm{ml}$ を加て，キレート生成を行った．又，力ラム中で キレート生成させるオンカラム誘導体化クロマトグラフ イーでは, 除タンパク処理した血清試料溶液 $1.0 \mathrm{ml}$ $0.5 \mathrm{M}$ 酢酸ナトリウム溶液 $4.0 \mathrm{ml}$ を加えた。いずれも $100 \mu \mathrm{l}$ をカラムへ注入し, $2 \cdot 2 \cdot 1$ 定量操作に従って $\mathrm{Cu}$ （II）及び(III）を定量した.

\section{3 結果と考察}

\section{$3 \cdot 1$ ピーク電流に及ぼす溶離液組成の影望}

Fig. 1 は溶離液にアセトニトリルと緩衝液の容積比 を(I) 1: 1 及び(II) 2:3 としたときの, $0.2 \mu \mathrm{g} / \mathrm{ml} \mathrm{Cu}$ （II）及び $\mathrm{Fe}$ (III) 標準溶液のクロマトグラムを示す. （I）の場合には保持時間 4 分 20 秒前後に二つのピーク が現れるが，これは試料中の溶存酸素，次いで $\mathrm{Cu}(\mathrm{II})$ による溶出ピークであり, 部分的に重なり合うため作図 法から $\mathrm{Cu}(\mathrm{II})$ のピーク高さを正確に求めるのは困難で あった。一方，（II）では，酸素と $\mathrm{Cu}(\mathrm{II})$ の溶出ピー クはベースライン上で完全に分離した，又(I)において は, 試料溶液中にあらかじめ窒素を通じることにより, 酸素の溶存ピークを無視できるほぼ小さくすることがで きるが, 操作が煩雑となるため, 本研究では溶離液とし て(II) 2:3アセトニトリル/緩衝液を選んだ。なお， 電気化学検出法の代わりに吸光検出法 $(420 \mathrm{~nm})$ を用

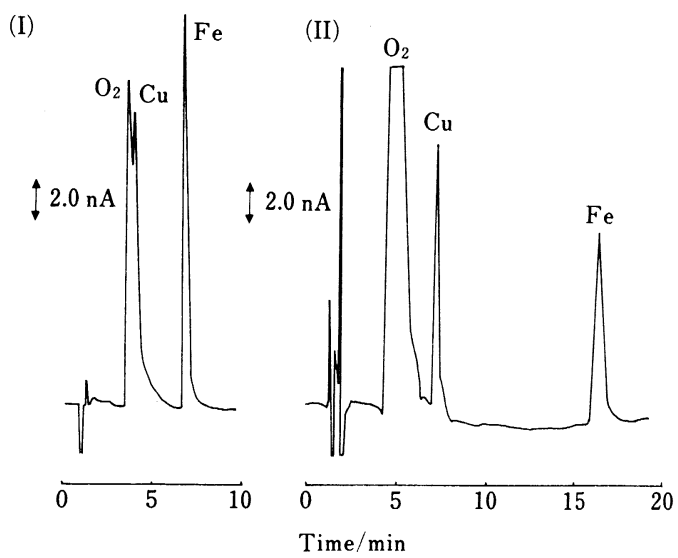

Fig. 1 Chromatograms for $\mathrm{Cu}$ and $\mathrm{Fe}$ oxinates with eluents of different volume ratio (acetonitrile $/ \mathrm{H}_{2} \mathrm{O}$ )

Metal concentration: $0.2 \mu \mathrm{g} / \mathrm{ml}$; (I) $1: 1$ acetonitrile $/ \mathrm{H}_{2} \mathrm{O}$; (II) $2: 3$ acetonitrile $/ \mathrm{H}_{2} \mathrm{O}$. Detection was made at $-0.40 \mathrm{~V}$ vs. $\mathrm{Ag} / \mathrm{AgCl}$. 


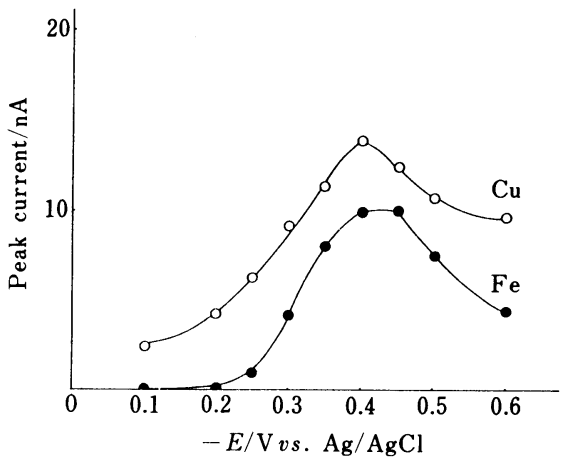

Fig. 2 Effect of applied potential on peak current Metal concentration : $0.2 \mu \mathrm{g} / \mathrm{ml}$

いた場合には, $\mathrm{Cu}(\mathrm{II})$ のピークが過剩試薬によるピー クと重なり合うために $\mathrm{Cu}(\mathrm{II})$ を定量するのは不可能で あった。

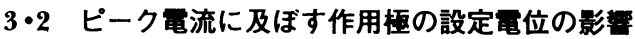

Fig. 2 は，作用極の設定電位 $-0.10 \mathrm{~V} \sim-0.60 \mathrm{~V}$ ま で変化させ, 得られたピーク電流とその電位との関係を 示したものである.両金属共に $-0.40 \mathrm{~V}$ 付近に極大を もつ川形の曲線となった．この極大ピーク電流が得られ る電位は，アセトニトリル中での $\mathrm{Cu}(\mathrm{II})$ 及び $\mathrm{Fe}$ (III) オキシン錯体のポーラログラフ半波電位 $-0.42 \mathrm{~V}$ 及び $-0.48 \mathrm{~V}$ 対銀/塩化銀電極とほぼ一致している. $-0.40 \mathrm{~V}$ 以上の設定電位ではピーク電流が減少した が,これは溶離液中の溶存酸素の還元が起こるために金 属錯体の電解効率が低下したためと考えられる. 本研究 では，作用極の電位を $-0.40 \mathrm{~V}$ に設定した。

\section{3・3 検量線}

$2 \cdot 2$ の実験操作に従って検量線を作成したところ $\mathrm{Cu}$ （II）及び $\mathrm{Fe}$ (III) 共に $0.02 \sim 2.0 \mu \mathrm{g} / \mathrm{ml}$ の濃度範囲で 良好な直線を示した。得られた回㷌㨁線は $\left(Y=i_{\mathrm{p}} / n \mathrm{~A}\right.$, $\left.X=C / \mu \mathrm{g} \mathrm{ml}^{-1}\right)$ は $\mathrm{Cu}(\mathrm{II})$ では $Y=69.1 X-0.15, \mathrm{Fe}$ (III) では $Y=49.5 X-0.25$ で, 相関係数はそれぞれ 0.9999 及び 0.9998 であった. 又, 検出限界 $(S / N$ 比を 3 としたとき）は両金属共に $0.01 \mu \mathrm{g} / \mathrm{ml}$ であった。

\section{$3 \cdot 4$ 実際試料の分析}

本法を和光純薬工業製管理血清中の $\mathrm{Cu}$ 及び $\mathrm{Fe}$ の定 量に応用した. Fig. 3 には, A 法で除タンパク処理操 作を行い，プレカラム誘導体化法で得られた代表的なク ロマトグラムを示す．（I）は管理血清 I (正常)，(II）

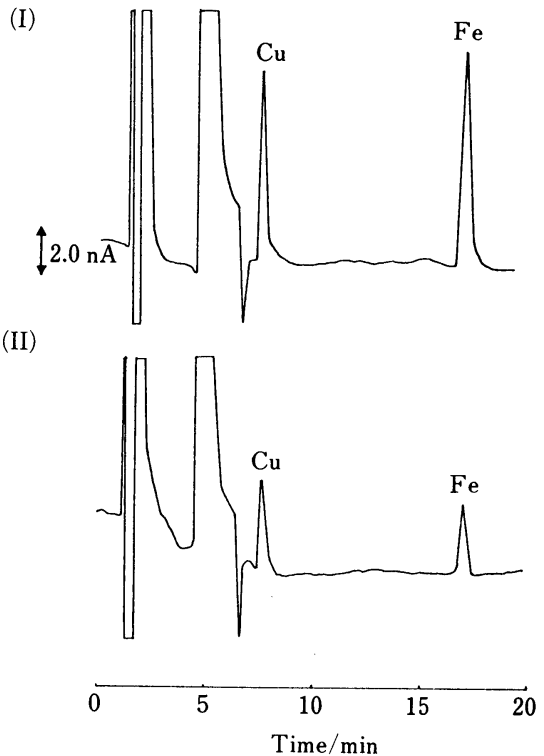

Fig. 3 Determination of $\mathrm{Cu}$ and $\mathrm{Fe}$ in control serum samples

(I) and (II) indicate control serum samples (normal) and (abnormal), respectively. Conditions are shown in Fig. 1. Samples were pretreated by method (A) and precolumn derivatization.

は管理血清 II (異常) を試料としたものである. Table 1 は得られた分析結果をまとめたものである.なお, 標 示量とは和光純薬工業社が比色法で求めた分析値であ る314). まず，プレカラム及びオンカラム誘導体化法に よる分析結果を比較してみると, オンカラム誘導体化法 では除タンパク操作の有無を問わず，標示量よりかなり 低い定量值を示した。これは, 試料水溶液を直接注入す るために, カラム内でのキレート生成が不完全であるこ とによるものと思われる. 一方, プレカラム誘導体化法 では，ほぼ標示量に近い定量值を与えており，この方法 を採用すべきである. 次に, 除タンパク処理操作による 定量值の違いを比較検討してみると, $\mathrm{A}$ 法では管理血 清 I 及びII について, 標示量に最も近い定量值が得ら れた. B 法の場合も $\mathrm{Cu}$ (II) 及び $\mathrm{Fe}$ (III) の定量值は 許容範囲内であった. 又 $\mathrm{B}$ 法は, 熱処理及びタンパク 質塊を砕く必要がなく操作が簡単である. C 法の場合 には, 管理血清 I 中の $\mathrm{Cu}(\mathrm{II})$ 定量值が, A 及び B 法 で得られた值よりやや低くはなるが許容範囲内であるの に対して, 管理血清 I 中の $\mathrm{Fe}($ III) の定量値は, 標示 量よりかなり低い值となった。確認のため, ロットナン バーの異なる管理血清 I 中の鉄を本法で調べてみたと 
Table 1 Analytical results $(\mu \mathrm{g} / \mathrm{dl})$ of $\mathrm{Cu}$ and $\mathrm{Fe}$ in control sera

\begin{tabular}{|c|c|c|c|c|c|}
\hline \multirow{2}{*}{ Method } & \multirow{2}{*}{ Sample } & \multicolumn{2}{|c|}{ Control Serum I } & \multicolumn{2}{|c|}{ Control Serum II } \\
\hline & & $\mathrm{Cu}$ & $\mathrm{Fe}$ & $\mathrm{Cu}$ & $\mathrm{Fe}$ \\
\hline \multirow[t]{3}{*}{ Precolumn } & A & $122 \pm 1$ & $204 \pm 4$ & $75 \pm 6$ & $65 \pm 5$ \\
\hline & B & $118 \pm 4$ & $192 \pm 6$ & $77 \pm 3$ & $65 \pm 5$ \\
\hline & $\mathrm{C}$ & $115 \pm 4$ & $98 \pm 4$ & $62 \pm 2$ & $62 \pm 5$ \\
\hline \multirow[t]{3}{*}{ Oncolumn } & A & $98 \pm 6$ & $118 \pm 5$ & $51 \pm 2$ & $43 \pm 5$ \\
\hline & B & $85 \pm 4$ & $126 \pm 5$ & $3 \pm 1$ & $64 \pm 2$ \\
\hline & C & $96 \pm 5$ & $57 \pm 1$ & $47 \pm 2$ & $43 \pm 4$ \\
\hline
\end{tabular}

Recommended values $(\mu \mathrm{g} / \mathrm{dl})-\mathrm{I}: \mathrm{Cu}=120 \pm 20, \mathrm{Fe}=180 \pm 18 ; \mathrm{II}: \mathrm{Cu}=70 \pm 15, \mathrm{Fe}=62 \pm 7$

ころ, $96 \pm 3(161 \pm 18) \mu \mathrm{g} / \mathrm{dl}$ 及び $84 \pm 3(161 \pm 18) \mu \mathrm{g} / \mathrm{dl}$ であり, 両者とも同様に低い定量結果が得られた. 更 に, C 法で管理血清 II を処理して得られた Cu(II) 及 び Fe(III) の定量值は標示量とよく一致しており，な ぜ管理血清 I 中の $\mathrm{Fe}$ 定量值のみが低くなるかは不明で ある. 試料中のなんらかの成分が定量を妨害している可 能性があり， $\mathrm{C}$ 法は使用すべきでない.

以上のことから，次のような結論が導き出せる. (1) あらかじめオキシン錯体を生成させておく，いわゆるプ レカラム誘導体化法がオンカラム誘導体化法より正確な 定量值を得ることができる. (2) 除タンパク処理操作と してトリクロロ酢酸を使用すると,この物質は発がん性 の疑いがあること及び熱処理なよ゙の煩雑な操作を行わな ければならないなどの久点がある.これに代わって, メ タノール・塩酸処理法は操作が簡単であり, しかも正確 な分析値が得られる. (3)本分析法は, 1 回の試料注入で 血清中の $\mathrm{Cu}(\mathrm{II})$ 及び $\mathrm{Fe}(\mathrm{III})$ を同時に定量できるこ
とから簡易であり，又多数の試料を短時間で分析できる 迅速性も備えており，臨床分析の分野で十分適用できる ものと思われる.

\section{文献}

1) S. S. Brown (Ed.): "Clinical Chemistry and Clinical Toxicology of Metals”, (1977), (Elsevier, NorthHolland, New York).

2) 日本分析化学会編: “分析化学便覧 (改訂二版)”, p. 1359 (1971), (丸善).

3) S. W. Meclean, W. C. Purdy: Anal. Chim. Acta, 69, 425 (1974).

4) R. E. Peterson: Anal. Chem., 25, 1337 (1953).

5) K. Kinson, C. B. Beleher: Anal. Chim. Acta, 31, 180 (1964).

6) M. Stoeppler, K. Brandt, T. G. Rains: Analyst (London), 103, 714 (1978).

7) A. M. Bond, Y. Nagaosa: Anal. Chim. Acta, 178, 197 (1985).

Comparison of pretreatment methods for the determination of copper and iron in serum by HPLC with electrochemical detection. Yukio NAGAOSA and Kazuhisa IsHIDA (Faculty of Engineering, Fukui University, 3-9-1, Bunkyo, Fukui-shi, Fukui 910)

Three different deproteinization methods for the liquid chromatographic determination of copper(II) and iron(III) in sera have been investigated for comparison. The analytical results obtained with both trichloroacetic acid-hydrochloric acid and methanolhydrochloric acid are in good agreement with the recommended values. The method using perchloric acid gave negative errors for the determination of iron(III) in a serum (normal). For accurate determination, it was found that the two metal complexes with 8-hydroxyquinoline should be formed prior to injection onto an ODS column.

(Received November 21, 1991)

\section{Keyword phrases}

deproteinization method; determination of copper(II) and iron(III) in serum; HPLC; electrochemical detection. 